December - 2006

\title{
Designing Websites for Learning and Enjoyment: A study of museum experiences
}

\author{
Aleck C. H. Lin and Shirley Gregor \\ The Australian National University
}

\begin{abstract}
This study reports on an exploratory research study that examined the design of websites that encourage both learning and enjoyment. This study examines museum websites that offer educational materials. As part of their mission, most museums provide the general public with educational materials for study and enjoyment. Many museums use the Internet in support of their mission. Museum websites offer excellent opportunity to study learning environments designed for enjoyment. Computer-supported learning of various types has been studied over the years, including computer-aided learning, computer-aided instruction, computer-managed learning, and more recently, learning via the Internet. Some relevant work appears in the literature on pleasure; however, the concept of online learning for enjoyment - specifically when learning is not part of a formal instructional undertaking - has not been well studied and thus is not well understood. This study seeks to redress this gap in the literature, specifically 'learning for enjoyment', by reporting on a number of semi-structured in-depth interviews with museum and educational experts in Taiwan. Our study identified a number of characteristics required of online learning websites, and we conclude some suggested guidelines for developing an online learning website for enjoyment.
\end{abstract}

Keywords: e-learning; learning; enjoyment; museum; website design

\section{Learning for Enjoyment}

A museum, as defined by the International Council of Museums (ICOM, 2006), is "a permanent institution in the service of society and of its development, and open to the public, which acquires, conserves, researches, communicates and exhibits, for purposes of study, education and enjoyment, material evidence of people and their environment.” Museums have a natural role as educational institutions. Ambrose and Paine (1994) state that a museum's educational mission is "to enhance the education of children and adults through the imaginative use of the museum and its collections" and "to assist the museum to maximise the educational potential of its collections, buildings and other resources” (p. 45). Thus, museums have the mission of providing study, education, and enjoyment for the general public (ICOM, 2006). With this mission in mind, museum websites offer an opportunity to study a particular kind of online learning (e-Learning), which is herein called 'learning for enjoyment.'

The aim of the study is to investigate how 'learning for enjoyment' can be encouraged through website design. This topic is important because museums are increasing their use of the Internet 
in support of their mission. In response to this institutional push for the global dissemination of human culture, ancient civilisation, and the arts online via the Internet, a new top level domain name, .museum (dot museum), has recently become operational (Museum Domain Management Association, 2006).

Computer-supported learning of various types and under various guises has been studied over the years. Current conceptualizations of e-Learning have progressively evolved from the traditional concepts of Computer-Aided Learning, Computer-Assisted Instruction, and Computer Managed Learning (Chang, 2001; Joint, 2003; Mazoue, 1999; Silberman, 1972; Tucker, 1997). e-Learning now attracts attention from those marketing of global enterprises' e-Learning investment and business perspectives (IBM, 2003; Fisher, 2002).

The concept of e-learning for enjoyment - specifically when learning is not part of a formal instructional undertaking - has been little studied and thus not well understood (Goldman \& Wadman, 2002; Schaller, Allison-Bunnell, \& Borun, 2005). Some relevant work appears in the literature on pleasure (Telfer, 1980), happiness (Perry, 1967; Veenhoven, 1984), playfulness (Lieberman, 1977; Webster \& Martocchio, 1992), and flow (Csikszentmihalyi, 1990; Pace, 2004). While all these concepts are related, they nonetheless differ from 'enjoyment' in subtle ways. This study seeks to redress this gap in the literature by exploring the concept of learning and its link to 'enjoyment.' We conclude with a conceptual guideline for building e-Learning websites for enjoyment.

As an exploratory study, a number of semi-structured in-depth interviews with museum and educational experts were conducted. These interviews allowed the researchers to gain insight into a number of perspectives and experiences regarding the development of e-Learning 'websites for enjoyment.'

The paper proceeds first by exploring the concept of enjoyment and related literature. Descriptions of the interviews are given, followed by the methods used and data analysis employed. The characteristics of a website that encourages learning are subsequently identified, and guidelines for developing 'websites for enjoyment' proposed.

\section{Conceptual Background}

Knowledge from a number of different areas was found to be relevant to our study, including eLearning in general and in museums in particular, the understanding of the concepts of enjoyment and learning for enjoyment, and website design. This section discusses the relevance of each of these topic areas.

\section{e-Learning}

The concept of e-Learning is relatively new and is defined as "a broad concept, encompassing a wide set of applications and processes which use all available electronic media to deliver vocational education and training more flexibly. The term 'e-Learning' is now used to capture the general intent to support a broad range of electronic media (Internet, intranets, extranets, satellite broadcast, audio/ video tape, interactive TV and CD-ROM) to make vocational learning more flexible for clients” (Australian National Training Authority, 2003, p. 3). The scope of e-Learning builds on prior work that has occurred in areas with diverse labels, including Computer-Aided Learning, Computer Assisted Instruction, and Computer Managed Learning. Previous studies in 
these fields have shown that computer-based education can maintain learners' attention, increase their motivation, and improve learning effectiveness (Beech, 1983; Gilliver, Randall, \& Pok, 1998; Thomas \& Kobayashi, 1987; Thompson, Higgins, \& Howell, 1991). Computer-Aided Learning represents an instructive environment in which a computer program is employed to assist users in learning. Computer-Aided Learning is not a solitary computer learning system, but part of an instructive approach devised to educate a specific subject (Joint, 2003; Tucker, 1997). Computer-Assisted Instruction provides a vehicle for providing extended practice to increase learner's ability (Chang, 2001). Cepni, Tas, and Kose (2006) found Computer-Assisted Instruction materials can improve student achievement, change misconceptions in some degree, and progress cognitive levels in science education domain. Wofford, Smith, and Miller (2005) used multimedia computer techniques, the use of graphics (animation, video) and/ or audio with or without using text support, to study Computer-Assisted Instruction in the healthcare sector. They believed that "Evolving computer technology and strategies will allow better targeting of the educational tasks amenable to computer-assisted education strategies" (Wofford, et al., 2005, p.156). Computer Managed Learning is the use of a computer to manage a learner's progress through study. In Computer Managed Learning, the computer is used to plan, organise, control, evaluate, and assess what the learner learns (Silberman, 1972).

It is significant that teaching and learning features of computer programs have changed with the influence of the Internet and developments in multimedia and interactive functions. The Australian National Training Authority (2003) gives two major characteristics of e-Learning: one is that e-Learning is assisted by information and communication technologies, and the second is that diverse media are needed for effective instruction and study purposes. Iverson (2004) proposed that successful e-Learning must not only be enjoyable and engaging, it must also be positive, supportive, active, collaborative, and contextual.

In contemporary museum research, several researchers recommend the use of multimedia and interactive functions to capture learners' attention and increase their learning experience (Horniblow, 2004; Marable \& Incognita, 2004; Neal, Magazine, \& Wormer, 2004; Schaller, et al., 2005). A few projects adopted $3 D$ virtual reality to design museum e-Learning websites (Kaye \& Poletto, 2004; Di Blas \& Poggi, 2006). The existing literature, however, does not provide general guidance as to the key factors in creating an enjoyable learning experience with a museum's website (Neal, et al., 2004) or, in fact, for e-Learning for enjoyment in general. This current study was performed against this background, with the aim of helping address the gaps in theoretical knowledge concerning learning for enjoyment and the design of websites that lead to enjoyable learning.

\section{Enjoyment}

Philosophers and psychologists have created a large body of literature relating to enjoyment, but definitions of 'enjoyment' vary. In philosophy, Perry (1967) argued that 'enjoyment' is a:

non-evaluative, non-conative pro-attitude toward some actual object for what it is in itself, which object is a present doing, undergoing, or experiencing on the part of the subject or is something which is intimately connected with a present doing, undergoing, or experience on his part. To be enjoying a thing or to be deriving enjoyment from it, is to have such a pro-attitude toward it. To enjoy or to derive enjoyment from a thing in a dispositional sense is to have a tendency to have this attitude toward it (p. 214). 
White (1964) believed that "to enjoy something . . . is to be having one’s desires satisfied" (p. 326).

In psychology, Davis (1982) expressed the view that "A is enjoying $\mathrm{E}$, if $\mathrm{E}$ is causing A to have a number of occurrent beliefs concerning $\mathrm{E}$, which collectively add significantly to the pleasure (happiness) A is experiencing” (p. 249).

Csikszentmihalyi (1990), known for the concept of 'flow,' sees the flow experience as a subset of enjoyment and also as a certain type of enjoyment. Csikszentmihalyi's view was that when people ponder about what makes their lives rewarding, they tend to move beyond pleasant memories and begin to remember other events and experiences that overlap with pleasurable ones, but fall into a category that deserves a separate name: enjoyment. Enjoyable events occur when a person has not only met some prior expectation or satisfied a need or a desire, but also gone beyond what they have been programmed to do and achieved something unexpected, perhaps something even unimagined before.

Warner (1980) defined enjoyment in a thorough way as: “To formulate the definition, let $\boldsymbol{t}$ ' be a moment of time slightly prior to $\boldsymbol{t}$; then we can say that: $\boldsymbol{x}$ (a person) enjoys an experience or activity $\mathbf{Z}$ at $t$ if and only if there is an array of concepts $\boldsymbol{C}$ such that

1. $x$ Zs at $t^{\prime}$;

2. $x$ 's Zing causes $x$ at $t$ :

(i) to believe, of his Zing, that the concepts in $\boldsymbol{C}$ apply to it;

(ii) to desire, of his $\boldsymbol{Z}$ ing, under the concepts in $\boldsymbol{C}$ that it occur;

3. $x$ desires for its own sake what (2, ii) describes him as desiring” (p.518).

The central idea behind this definition is that enjoyment consists of a certain harmony between three elements: the activity or experience itself; the concepts which this activity or experience causes you to believe to apply to it; and a certain desire in which these same concepts figure (Warner, 1980). When dissecting this definition, three vital concepts can be extracted. First is the factor of engagement in an activity. The fundamental assumption in Warner's definition is that enjoyment is related to 'an experience or activity,' that the person was doing something that engaged his/ her cognition and feeling. Furthermore, the thing a person was doing attracted their attention. The definition of enjoyment from Cobuild (2003) also supports this construct: "Enjoyment is the feeling of pleasure and satisfaction that you have when you do or experience something that you like” (p. 470).

Second is the factor of 'positive affect.' The words 'to believe, of his Zing, that the concepts in $\mathbf{C}$ apply to it,' and 'to desire' the concepts in $\mathbf{C}$, imply that that the activity done by a person leads to some desirable positive affects, for instance a feeling of pleasure or happiness. The definition of 'enjoyment' according to Davis (1982), and as articulated by Perry, (1967): “To enjoy or to derive enjoyment from a thing in a dispositional sense is to have a tendency to have this attitude toward it” (p.214) support this view, as does Seligman and Csikszentmihalyi's (2000) who wrote: "Enjoyment refers to the good feelings people experience when they break through the limits of homeostasis" (p. 12).

The third factor is 'fulfillment:' " $x$ desires for its own sake” what happens from his "Zing”; that is, it fulfills some need. Csikszentmihalyi (1990), states that "Enjoyable events occur when a 
person has not only met some prior expectation or satisfied a need or a desire but also gone beyond what he or she has been programmed to do and achieved something unexpected, perhaps something even unimagined before" (p. 46). In addition, White (1964) mentioned that "To enjoy something . . . is to be having one's desires satisfied” (p. 326). All these definitions provide a basis for the idea that 'enjoyment' means the meeting and fulfillment of a person's needs .

\section{Learning for Enjoyment}

Schaller et al. (2005) note that "Research into computer-based informal learning is rare, particularly for studies focusing on Web-based informal learning.” One significant case from Di Blas and Poggi (2006) report on two 3D game-based online learning programs designed for cultural heritage and education: Learning@Europe and Stori@Lombardia. Dia Blas and Poggi’s study found students felt fulfilled in going through these programs. Moreover, the programs motivated students to learn, noting: "Games and activities are fundamental parts of the experience: they keep students busy, they are exciting and engaging. ('When we won, students roared as if they were at a soccer match,' reported one Italian teacher)” (Di Blas \& Poggi, 2006). Gee (2003), Prensky (2000), and Steinkuehler (2004) proposed that online games and video games can engage users' activities and retain their concentration on tasks to learn some complex information. Participants in Learning@Europe obtained motivation and goals to push them to learn hard (Di Blas \& Poggi, 2006).

There is still the question of how exactly 'enjoyment' is associated with learning. To consider this question, we must refer back to the prior definitions of 'enjoyment,' which include the idea that an enjoyable activity meets a person's need or fulfills some desire. The idea of meeting needs leads us to theories of human motivation.

There are many theories of human motivation, with one of the best-known being illustrated in Maslow's hierarchy of human needs (Maslow, 1987). Here we make use of a later work by Ford (1992), which provides an integrating view of a number of other theories. Ford (1992) in Motivating Humans categorised human goals as follows:

A.) Affective Goals, including entertainment, tranquility, happiness, bodily sensations, and physical well-being goals

B.) Cognitive Goals, including exploration, understanding, intellectual creativity, and positive self-evaluations goals

C.) Subjective Organization Goals, including unity and transcendence goals

D.) Self-Assertive Social Relationship Goals, including individuality, self-determination, superiority, and resource acquisition goals

E.) Integrative Social Relationship Goals, including belongingness, social responsibility, equity, and resource provision goals

F.) Task Goals, including mastery, task creativity, management, material gain, and safety goals. 
According to Ford's arguments, there are two fundamental characteristics of these human goals, the first is that they represent the consequences to be achieved, and the second is they direct the attention of the person to the achievement of those consequences. The first three goal categories represent within-person goals, and the last three categories represent goals with respect to the relationships between people and their environments (Lawton \& Gregor, 2002).

Figure 1. illustrates how the concepts of learning and enjoyment can be related analytically. The 'Positive Affect' aspect (the second characteristic of enjoyment) includes the notions of pleasure, happiness, and good feelings which can break through the limits of homeostasis. This corresponds to the first category (A) of happiness, bodily sensations, and physical well-being goals found in Ford's taxonomy, 'the affective goals.' The 'Fulfillment' aspect of enjoyment arises when some needs are fulfilled, including several categories of Ford's taxonomy: Category A of entertainment and happiness goals; also Category B goals of exploration, understanding, intellectual creativity, and positive self-evaluations ; Category C goal of transcendence; Category $\mathrm{D}$ goal of resource acquisition; Category $\mathrm{E}$ goal of resource provision; and/ or Category F goals of task creativity and management. The conclusion is that enjoyment can be derived from learning, as learning satisfies a number of human needs, but it needs to be learning that is accompanied by positive affect.

Figure 1. Enjoyment Arising from Learning

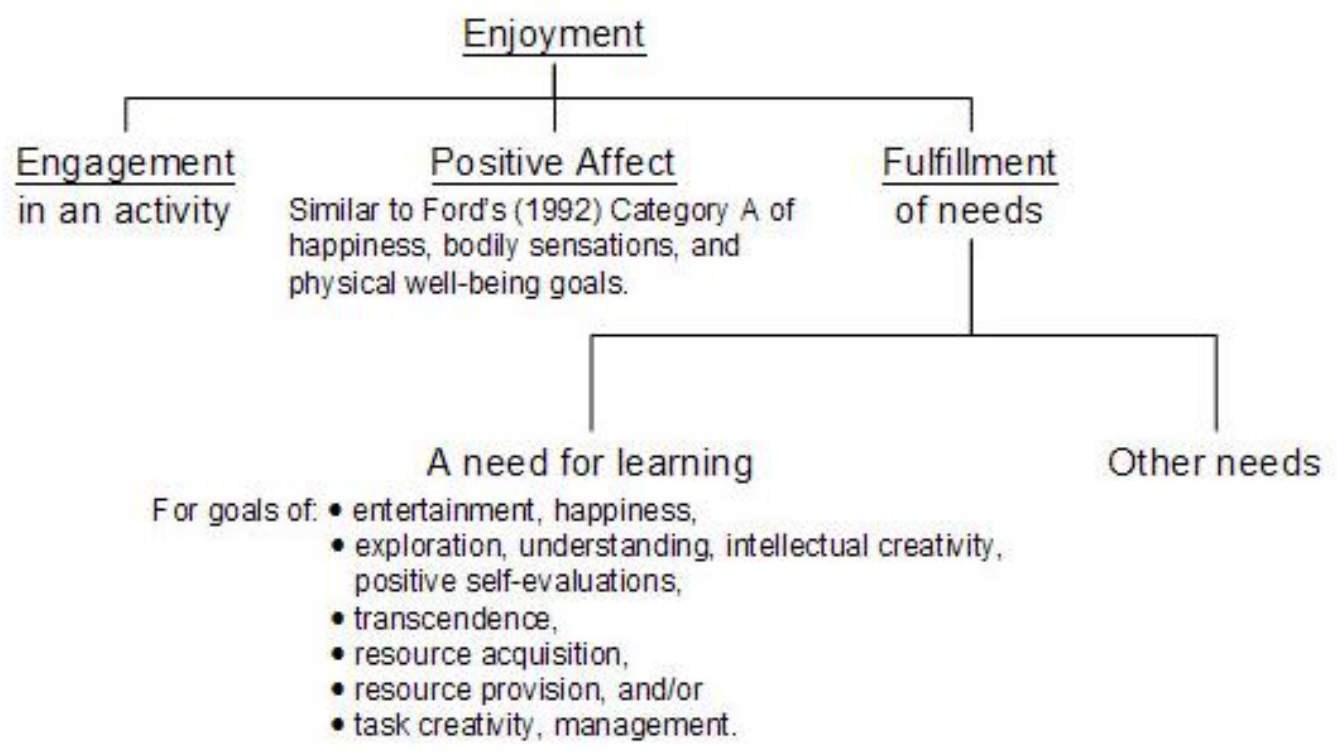

Several types of learning do not fit with 'learning for enjoyment.' They arise when extrinsic motivation occurs, such as when force is applied or learning for material gain. Hence, visitors to museum websites are likely to have intrinsic rather than extrinsic motives for learning. In this context, making a learning experience enjoyable is additionally important. However, even though website design has been contemplated for many years, the guidelines for developing an online learning website for enjoyment, especially within the museum sphere, are still relatively unexplored, which leads us to the next section. 


\section{Website Design}

Goldman and Wadman (2002) expressed "Although the field of distance education is rich in studies, little of it was transferable to museum websites". When we came to the questions of what are the characteristics of a museum website that encourages learning, and what are guidelines for developing an online learning website for enjoyment, we found remarkably little to guide us.

There is an extensive literature on website design and human-computer interaction in general. For example, Powell (2002) thought that there are five areas that cover the major facets of website design, and asserts that designers should keep these in mind at all times. These areas are content, visualization, technology, delivery, and purpose. Jakob (2000) considers that poor information architecture will always lead to poor usability. In looking at knowledge transfer in particular, Stopsky (2000) argues that interactive characteristics and immediate access to any type of information make the Web a particularly useful medium for the creation of knowledge.

The phenomenon of enjoyment, however, is believed to have unique characteristics that discriminate it from traditional usefulness, ease of use, and user acceptance of websites in important ways (Blythe \& Wright, 2003). There are few studies that treat with this specific aspect of website design.

Some studies have been carried out on the 'flow' phenomenon, which in our terms is a particular type of enjoyment. The notion of 'flow' was initially applied to the experiences of website users by Hoffman and Novak (1996) in an assessment of Internet marketing activities. Pace (2004) presented a grounded theory of the flow experiences of Web users engaged in informationseeking activities. Pace (2004) mentioned that curiosity and interest play a vital role in the flow experiences of website users. Moreover, Pace showed that appealing content and links also sustain and attract a website user's concentration. Congruence with personal interests and novelty were also two major factors. The characteristics of a website such as credibility, correctness, currency, ease of understanding, rarity, emotional impact, and aesthetic appeal are also influential in maintaining a user's concentration under some conditions.

From the studies of flow, especially Pace (2004), we expect that good website design will be a pre-condition for enjoyable learning to occur. Learners experience the usability of an e-Learning website from the first moment they encounter the website. If they encounter poor usability, the chance of further use of the website decreases, with a subsequent effect on both learning and enjoyment.

\section{Method}

The design of this study uses a descriptive qualitative approach based on semi-structured in-depth interviews and expert interviews as the primary method. Qualitative research is relevant to the study of social relations (Berg, 1989; Flick, 2003). In-depth interviews are "between the researcher and informants directed toward understanding informants' perspectives on their lives, experiences or situations as expressed in their own words" (Taylor \& Bogdan, 1984, p. 77). Minichiello, Aroni, Timewell, and Alexander (1990) considered: "It is more usual to see this method being employed as part of an exploratory study where the researcher is attempting to gain understanding of the field of study, and to develop theories rather than test them” (p. 101). Furthermore, they noted that to adopt this research method as one's research approach or data- 
collection method is connected to theoretical and practical deliberation, which means that the researcher realises what social reality is and how it ought to be studied.

The expert interview is a special form of semi-structured in-depth interview, as it is linked to the expectation that the interviewed subjects' viewpoints are to be expressed in a relatively openly designed interview situation (Flick, 2003). Dorussen, Lenz, and Blavoukos (2005) believed that expert interviews can provide a distinctive supply for 'inside' information about the policymaking process. Awad and Ghaziri (2004) in Knowledge Management defined an expert as "someone who knows what he or she does not know and is the first one to tell you so. Firms hire experts to benefit from their experience and proven knowledge in solving complex problems"(p. 34). They believed that when interviewing an expert, a knowledge developer should obtain an opportunity to confirm information and receive the expert's thinking process dynamically. To collect and analyse the affairs and processes experienced by experts is a conduit to knowledge acquisition (Moody, Blanton, \& Will 1998/ 99). To interview experts includes not only knowledge elicitation, but also autonomous learning processes. Awad and Ghaziri (2004) proposed several advantages for interviewing experts, including the flexibility of investigating regions about which little is known, a better opportunity for assess the validity of information attained, and a valuable method for educing information on complex subjects.

Goldman and Wadman (2002) noted that most studies of museum websites were based on quantitative research methods. Qualitative studies were few, however. When investigating how to design websites for learning and enjoyment, the information we felt we needed was not commonly available in books, journals, computer databases, or on the Internet. We also realised that we encountered a very complex topic which needed initial broad understanding. Therefore, this study adopted a qualitative research method of expert interview as the primary research approach.

The sampling selection strategy employed was purposeful sampling, where information-rich cases are selected (Patton, 2002). Information-rich cases are those from which the researcher can learn about the issues of central importance of the research. Five experts in Taiwan were selected as subjects with the following criteria in mind. All were currently working in a museum or related educational institution, in which one or several e-Learning projects were launched, executed, or managed by them. All had been employed in their current position for more than three years. All had educational, e-Learning, or informatics and communications technology backgrounds or experiences. Table 1 shows the profile of the experts participating in this study.

Table 1. Profiles of experts participating in the study

\begin{tabular}{lllllr}
\hline Expert & Institution & Gender & Functional Area & $\begin{array}{l}\text { Educational } \\
\text { Level }\end{array}$ & In Position \\
\hline E1 & Museum & $\mathrm{M}$ & Systems Management and E-Learning & PhD & 3 Years \\
E2 & Museum & $\mathrm{F}$ & Web Design and E-Learning & Masters & 5 Years \\
E3 & Museum & $\mathrm{M}$ & Information Technology and Museum Education & Masters & 17 Years \\
E4 & Educational Institution & $\mathrm{M}$ & Information Systems and Research & PhD & 3 Years \\
E5 & Educational Institution & $\mathrm{F}$ & Education and E-Learning & Bachelors & 18 Years \\
\hline
\end{tabular}

Each interview took approximately 1.5 hours. The primary approach to data analysis was content analysis, which is a research method that uses a set of procedures to make valid inferences from text (Weber, 1990). The procedures for the study were based on the general procedures illustrated 
by Rossman and Rallis (2003) and using the concepts of Eisenhardt (1989) for generating theory from case studies.

The interview protocol explored the following major questions:

- What have been your experiences with e-Learning websites in your organisation?

- $\quad$ Do you think that an e-Learning website can encourage learning by the general public? If Yes, how? If No, why not?

- What are the conditions for creating an enjoyable learning experience with an e-Learning website?

- How can a website for the enjoyment of e-Learning be developed?

\section{Findings and Results}

The interviews were transcribed and analysed for the key concepts in the interviewees' responses. This data gave rise to a description of the features that were believed to characterise a website that encouraged learning and the conceptual guidelines for designing an e-Learning website for enjoyment.

\section{Features of an e-Learning Website that Encourage Learning}

The experts all proposed significant features that they believed encouraged learning from a museum's e-Learning website, including aesthetic appearance, interactivity, ease of use, asynchronous and free accessibility and, simplicity (relaxing and short tasks), and partnerships (provision of useful hyperlinks). Table 2 summarizes the features identified from the narratives of all the experts. In the description of the experts' views that follow, their personal experiences and beliefs are related to confirming research literature.

\section{Feature 1. Appearance}

Expert 1 felt that good website design was one of the major factors influencing the enjoyment of learning. Similarly, Expert 4 deemed that visual design is the most important thing for encouraging the enjoyment of learning and that a good visual design would encourage people to look deeper into a website (taking account of colour, text format and size, and image size). Expert 2 also believed that the colours in a website would make visitors decide how long they would stay at a website. These findings are congruent with much Human-Computer Interaction literature, including Blythe Overbeeke, Monk, and Wright (2003), Carroll (1991), Preece, Rogers, Sharp, Benyon, Holland, et al. (1994), and Tarasewich, Harold, and Hampton (2001). Tarasewich et al. (2001) report that aesthetics play a valuable component in one's overall experience, and Pace (2004) mentioned that aesthetic appeal is one of the characteristics that influences and maintains a user's concentration under some circumstances. 


\section{Feature 2. Interactivity}

One of the experts suggested increasing interaction with learners on the website as a first step in motivating e-Learning. Interactivity could involve games, e-cards, emailing greeting functions, voting for favorite objects or exhibitions, and providing some form of reward. These functions can motivate and increase learners' participations and attentions. Cohen and Payiatakis (2002) suggested similar concepts in that e-Learning has to be compelling and appealing to maintain the learner involved and interested. Further, learning experiences have to become memorable and motivational if they are to make a lasting impact on learners.

\section{Feature 3. Ease of Use}

Two experts in website design considered that museums should rethink and restructure their eLearning websites when new content and new functions are added to the original e-Learning website, because these new contents and functions would affect the original presentation of the website and make the interface more complex. Expert 2 believed that the frame of the website should make it easy and quick for people to navigate and find what they want. Expert 4 believed that the structure of the website should not be complicated, citing "ease of use" and "trouble-free navigation" as two foremost factors.

\section{Feature 4. Accessibility}

Expert 3 noted that the museum's e-Learning courses would usually be accessed worldwide. Learners in this virtual environment would learn asynchronously. Every individual learner should be able to learn in a flexible way - at their own time, pace, and place because when they are distributed globally, it is difficult for them to stay together at the same time for one particular synchronous course. Horton (2000) defines 'asynchronous' in Web-based training as meaning that learners can undertake learning whenever they want - learners can read courses or learning materials at any time. Moreover, Expert 3 expressed that the e-Learning courses developed by museums should be free for the general public.

\section{Feature 5. Simplicity (Relaxing and Short Tasks)}

Three experts observed that the contents of courses designed for a museum e-Learning website should not be abstruse or long-winded, because most learners visit museum websites other than for the formal purposes of studying. Expert 2 expressed that " . . . most of the purposes to visit a museum's website are for interests and relaxation," and moreover, if an e-Learning course is designed only from the viewpoints of experts, it would become too abstruse and the general public would not understand it or learn from it easily. Jakob (2000) states: "Ultimately, users visit your website for its content. Everything else is just the backdrop . . .” (p. 99). This statement suggests that the design should be user-centred and not just from the designer's view. Although Web-based technologies can provide an effective yet inexpensive way to test knowledge, skills, and attitudes (Horton, 2000), some of the experts suggest that too many tests at the end of a museum e-Learning course were counter-productive. Most visitors are aiming to learn for relaxation and to obtain more extensive knowledge. They do not join the e-Leaning programs offered as a public service by museums for the purposes of tests or getting a high score. 


\section{Feature 6. Partnerships}

Expert 3 believed that museums should collaborate with schools to adopt museum e-Learning courses for teaching, as this practice would encourage potential users to access those courses. Moreover, museums would then have the opportunity to obtain feedback to evaluate and improve their courses and the design of their e-Learning website. Expert 2 considered that museums could also exchange links to their website with some commercial portals, to increase traffic and thus, their popularity. This type of promotion would theoretically raise awareness of the website among the general public, and thus learning behaviours could indirectly be encouraged. Connecting to different types of learning resources is also another vital aspect in museum e-Learning websites. It is understood that such tactics will extend learners' breadth of the knowledge because they can visit other relevant and helpful websites. Powell's (2002) opinion is that each link presents a door and the link label is thought to specify what is beyond each door. Therefore, the provision of useful hyperlinks and external resources, would be a factor for designing museum e-Learning websites.

Table 2. Illustrative narrative extracts for features of an e-Learning website

\begin{tabular}{lll}
\hline Feature & Expert & Narrative extracts \\
\hline $\begin{array}{l}\text { Feature 1. } \\
\text { Appearance }\end{array}$ & E1 & $\begin{array}{l}\text { It is understood that the good design of the website interface, the course contents, and } \\
\text { the attractive functions would all be the factors to influence the enjoyment of learning } \\
\text { - } \begin{array}{l}\text { The visual design of the National Palace Museum's website is very beautiful and } \\
\text { charming, which could be very attractive. }\end{array}\end{array}$
\end{tabular}

E2 - Chose the website colour set cautiously because the colours of a website will make visitors decide how long they will stay at your website.

E4 - The most important thing would be the visual design. A good visual design would encourage people to look deeper in a website, which includes colour, text format and size, image size.

Feature 2. E2 - . . .to increase interactions with learners on the website, such as games, e-cards, e-mail Interactivity greeting functions, the votes of favourite objects or exhibitions, and provide some little gifts to attract participations. This will keep people visiting the website frequently to see what's new.

Feature 3. E1 - . . .it is important to evaluate and analyse this kind of information systems before Ease of Use constructing it.

E2 - To rethink and redesign the structure of the website is also an important thing, especially when new content and/or new functions are added to the original e-Learning website. The frame of the website should make people easier and quicker to navigate and find what they want.

E4 - The structure of the website should not be complicated. "Easy to use" and "troublefree to navigate” are important factors. 
- "Design", included designing concepts and designing techniques, is very important fro developing an e-Learning website.

- System analysis is also an important aspect.

Feature 4. E3 Accessibility
Feature 5. E1 Simplicity (Relaxing and Short Tasks)
- ...to provide asynchronous learning functions is very important. This means that every individual learner can learn in a more flexible way - in their own time, pace, and place.

- Asynchronous learners become independent learners. Independent learning - having people think for themselves and figure things out for themselves - certainly is a museum's educational objective.

- "Free" will be another key factor. Learners will be frustrated if they find the information or courses provided from the website are needed to charge.

E1 - The current Bronze e-Learning course has twelve chapters. It is too long. Learners do not have patience to finish the whole course.

- ....an unforced final exam is designed at the end of the bronze course, but only $1 / 10$ registered learners took the test. Most of the learners do not like to be tested.

E2 - The learning contents with twelve chapters are designed from the viewpoints of experts and are become too abstruse, general public can't realize or learn from them easily.

- ...do not construct too many tests at the end of the course. People would like to learn something from your museum's Website, of course. But most of the purposes to visit a museum's Website are for interests and relaxation.

- The contents of the course should not be very enormous and complex, which means that learners can read through and find some useful information quickly.

Feature 6.

E2

Partnerships
- ...to consider the museum marketing. Try to access the famous portals' banners, to join international competitions, and to exchange the hyperlink with other museums and relevant organisations.

E3 - ...to connect with schools, local communities, and businesses. With their participations, the website will be promoted and evaluated in an adequate way.

E4 - From the e-Learning website, you should provide as many as hyperlinks to connect different kinds of resources from other e-Learning websites or sources.

\section{Development Guidelines for an e-Learning Website for Enjoyment}

Five development guidelines for designing websites for enjoyment and learning were extracted from the interviews and covered several dimensions, including adopting multimedia and 
interactive technologies, self-directed learning, sharable considerations, and museum's internal and external resources. Table 3 provides illustrative narrative from the experts.

\section{Adoption of Multimedia and Interactive Technologies}

All of the experts provided an opinion related to multimedia and interactive functions. A number indicated that multimedia and interactive learning functions could easily catch and hold users' attention. Forrester and Jantzie (2004) proposed that multimedia allows instructors and designer to bring the real world to the learners through the use of audio and visual functions. Lawton and Gregor (2002) analysed the uses of Internet interactivity for marketing and suggested that in the Internet environment, non-passive, user-pull, and interactive tools have the greatest potential to add value.

\section{Considering the Characteristics of Self-Directed Learning}

The majority of the experts regarded the function of self-directed learning as a vital element. One expert considered that self-directed learning is a museum's educational objective. Another expert identified self-directed learning as a future trend in education. Knowles (1975) outlines the advantages of self-directed learning: firstly, people learn more things and learn better than those who wait passively to be taught; secondly, people enter into learning more purposefully and with greater motivation; and thirdly, people tend to retain and make use of what they learn better and for longer. This guideline matches well with the idea of the intrinsic motivation needed to underpin 'learning for enjoyment.'

\section{Have Qualified Staff and Adequate Financial Support}

Expert 1 commented on the need for professional design techniques and use of creative staff for the development of enjoyable multimedia and interactive learning functions. This need is noted by other scholars. Sommerville (2001), for example, sees systems engineering as an interdisciplinary activity involving teams drawn from different backgrounds, thus good system engineering requiring teams with wide knowledge to consider all implications. Therefore, the availability of qualified staff affects the success of the e-Learning website. Moreover, without good financial support, it is not easy to design such e-Learning websites, which are expensive to develop.

\section{Consider the Targeted Audience}

One expert commented on the need to consider what type of people visit a museum's website, and what are the major targets of a particular e-Learning course. Focusing on user-centred design aspects, Powell (2002) reported that users can be classified into three levels: novices, intermediates, or expert/ power users. Marable and Incognita (2004) also found that users of a museum website might range from broad interest visitors with slight knowledge of the topic, to instructors looking for supporting resources, to recreational scholars using the website as an auxiliary research tool. When designing such a website, it is therefore essential to consider different levels of targets. Powell (2002) suggests that even though designers do not need to 'perfectly accommodate' every user's preference and necessity, they should still develop an adaptive interface which can be suitable for these three broad categories of users: novices, intermediates, or expert/ power users. Moreover, he advises that "be particularly careful not to 
lock users out, particularly those who may be disabled or slightly different from your average user” (Powell, 2002, p. 63).

\section{Make the Information More Sharable}

One expert recommended that the platform of e-Learning websites should try to follow the Sharable Course Object Reference Model (SCORM) international standards to make all the information more sharable. SCORM aims to establish a mechanism for repeated use and sharing of courseware that is acceptable in different learning management systems (Yang \& Ho, 2005). Although it is still a debatable perspective, this expert envisions learners interacting with learning contents on museum websites that are both globally delivered and globally accessible.

Table 3: Illustrative narrative extracts for the design of an e-Learning website for enjoyment

\begin{tabular}{|c|c|c|}
\hline Guidelines & Expert & Narrative \\
\hline \multirow{5}{*}{$\begin{array}{l}\text { Guideline } 1 . \\
\text { Adopt } \\
\text { Multimedia and } \\
\text { Interactive } \\
\text { Technologies }\end{array}$} & E1 & $\begin{array}{l}\text { Most of the multimedia and interactive development techniques are not mature and } \\
\text { popular enough and the developed costs are still expensive. }\end{array}$ \\
\hline & E2 & $\begin{array}{l}\text { We designed the sections of Kid's Corner, Digital Museum, and E-Learning for our } \\
\text { museum's education objectives. There are many multimedia and interactive } \\
\text { functions applied in these categories, including Flash objects and audio and visual } \\
\text { functions. }\end{array}$ \\
\hline & E3 & $\begin{array}{l}\text {-..Some multimedia and interactive systems will be employed in the near future, } \\
\text { such as the video-on-demand online learning system, wireless and mobile tour } \\
\text { guide, and wireless electronic schoolbook. }\end{array}$ \\
\hline & E4 & $\begin{array}{l}\text { - Multimedia and interactive functions could also promote the enjoyable learning } \\
\text { experience. }\end{array}$ \\
\hline & E5 & $\begin{array}{l}\text { - ..to design some interactive functions to catch learner's attention and to make them } \\
\text { feel that learning from the Website could be so interesting and exciting. }\end{array}$ \\
\hline \multirow{4}{*}{$\begin{array}{l}\text { Guideline } 2 . \\
\text { Consider the } \\
\text { Characteristics } \\
\text { of Self-Directed } \\
\text { Learning }\end{array}$} & E1 & $\begin{array}{l}\text { - It (the NPM's E-Learning Website) also becomes a medium for self-directed } \\
\text { learning. The self-directed learning will be a tendency for the future educational } \\
\text { function. }\end{array}$ \\
\hline & E2 & $\begin{array}{l}\text { - How to attract people to visit the museum's website and how to serve people to } \\
\text { learn by themselves are important questions for us when designing the e-Learning } \\
\text { website. }\end{array}$ \\
\hline & E3 & $\begin{array}{l}\text { - Asynchronous learners become independent learners. Independent learning - have } \\
\text { people think for themselves and figure things out for themselves - certainly is a } \\
\text { museum's educational objective. }\end{array}$ \\
\hline & E5 & $\begin{array}{l}\text { - Students also can study at home by themselves at anytime and anywhere. } \\
\text { - Some extra readings on the websites are listed in the handouts, so student can } \\
\text { choose some websites to learn by themselves. }\end{array}$ \\
\hline
\end{tabular}




\begin{tabular}{|c|c|c|}
\hline $\begin{array}{l}\text { Guideline } 3 . \\
\text { Have Qualified } \\
\text { Staff and } \\
\text { Adequate } \\
\text { Financial } \\
\text { Support }\end{array}$ & E1 & $\begin{array}{l}\text { - We have high quality human resources (a professional website design and } \\
\text { development team) and adequate financial support from government. }\end{array}$ \\
\hline $\begin{array}{l}\text { Guideline } 4 . \\
\text { Consider the } \\
\text { Targeted } \\
\text { Audience }\end{array}$ & E3 & $\begin{array}{l}\text { - When designing e-Learning in the museum, it is necessary to consider the following } \\
\text { questions, such as what kind of people will visit the museum's website, what are the } \\
\text { major targets of a particular e-Learning course. }\end{array}$ \\
\hline $\begin{array}{l}\text { Guideline } 5 . \\
\text { Make the } \\
\text { Information } \\
\text { More Shareable }\end{array}$ & E4 & $\begin{array}{l}\text { - The platform should follow the Sharable Course Object Reference Model (SCORM) } \\
\text { international standards to make all of the information become more shareable and } \\
\text { transformable. }\end{array}$ \\
\hline
\end{tabular}

\section{Limitations to the Study}

Before concluding, the limitations of the study should be acknowledged. Flick (2003) proposed that the collection of interview data could be stopped when reaching the criterion of 'theoretical saturation' and 'saturation means that no additional data are being found.' As an exploratory study, only five experts were interviewed and therefore interviewing a larger sample may have yielded additional guidelines. Moreover, this study examined the designer's point of view; the user's view was not considered. These limitations will be addressed in further research.

\section{Conclusion}

A successful e-Learning website is thought to be enjoyable and engaging, positive and supportive, active, collaborative and contextual (Iverson, 2004). This study further explored the nature of e-Learning for enjoyment through a grounded study with five experts drawn from the field of museum website design in Taiwan. Interviews with these experts allowed insights into key factors affecting website design from those with considerable experience in the field.

Six features for encouraging online learning for enjoyment, including 1.) attractive appearance, 2.) increasing interaction with learners, 3.) ease of use, 4.) asynchronous accessibility, 5.) relaxing and short tasks, and 6.) provision of useful hyperlinks were integrated from the experts' viewpoints. Furthermore, five development guidelines for designing learning for enjoyment in museum websites were investigated: 1.) adopting multimedia and interactive technologies, 2.) considering the characteristics of self-directed learning, 3.) having qualified staff and adequate financial support, 4.) considering the targeted audience, and 5.) making the information more sharable.

While the findings of this study support findings from other related literature, the expert interviews reported in this paper highlight the key features of designing for 'e-Learning for enjoyment,' research which has not been done before in a formal study. Not unexpectedly, this study's finding that ease-of-use, appearance, user-centred design, and employment of wellresourced qualified staff, are important and is congruent with general principles of human-centred design (e.g., Preece et al., 1994). The findings in this study also align with Pace's (2004) study of 'flow,' which found that features such as ease of understanding and aesthetic appeal contributed 
to users' flow experience. Pace (2004) also showed that appealing content and links were important, a finding that was again supported in this study.

Other findings of this study (not so obvious in previous literature) explore the museum website experts' depth of experience with website development for enjoyable learning. These features include: interactivity, lower complexity (i.e., short and few tasks), and the consideration of selfdirected learning. The value of the study lies in its identification of these specific features that the experts see as central to their mission of providing enjoyable online learning in museum contexts. Additionally, this study, through its in-depth consideration of enjoyment as a construct, shows conceptually the linkage between enjoyment and learning.

Expert 2 opined: “Without digitisation and Internet technologies, we can't provide the whole of ancient knowledge in such deep going and detailed form.” In the new era, e-Learning in museums can be a vehicle that helps to spread and promote the knowledge of civilisation. Learners will be able to enhance their own learning needs, interests, and optimal experiences. From this study, successful e-Learning in museum initiatives today requires:

- A strategy that tightly links e-Learning with institutions and learners' needs

- Encouragement, experiences, and intriguing content that make learning enjoyable, compelling, and engaging to target the museum audiences' needs

- A visual-driven and self-directed design that bring the real world to the learners through the use of audio and visual functions, where learners can gain from self-paced instruction based upon multimedia and interactive learning technologies

- Supported internal and external resources for museums, including qualified staff and adequate financial supply, and connections with schools and businesses.

\section{References}

Ambrose, T., \& Paine, C. (1994). Museum Basic. London/ New York: ICOM/ Routledge.

Australian National Training Authority (2003). Definition of Key Terms Used in e-Learning. Australian Flexible Learning Framework Quick Guides Series. Retrieved August 1, 2006 from: http://www.flexiblelearning.net.au/guides/keyterms.pdf

Awad, E. M., \& Ghaziri, H. M. (2004). Knowledge Management. Upper Saddle River, NJ.: Pearson Education.

Beech, G. (1983). Computer Based Learning: Practical methods for microcomputers. Wilmslow, UK.: Sigma.

Berg, L. B. (1989). Qualitative Research Methods for the Social Sciences. Boston: Allyn \& Bacon.

Blythe, M. A., Overbeeke, K., Monk, A. F., \& Wright P.C. (2003) (Eds.) Funology: From usability to enjoyment. Netherlands: Kluwer Academic. 
Blythe, M. A., \& Wright, P. C. (2003). Introduction - From Usability to Enjoyment. In M. A. Blythe, K. Overbeeke, A. F. Monk, \& P.C. Wright (Eds.) Funology: From usability to enjoyment. Netherlands: Kluwer Academic.

Carroll, J. M. (1991). Designing Interaction: Psychology at the Human-Computer Interface. Cambridge MA.: Cambridge University Press.F

Cepni, S., Tas, E., \& Kose, S. (2006). The effects of computer-assisted material on students’ cognitive levels, misconceptions and attitudes towards science. Computers and Education, 46(2), 192-205.

Chang, C. Y. (2001). A Problem-Solving Based Computer-Assisted Tutorial for the Earth Sciences. Journal of Computer Assisted Learning, 17(3), 263-274.

Cobuild, C. (2003). Advanced Learner’s English Dictionary. London: Harper Collins.

Cohen, S. L., \& Payiatakis, D. (2002). e-Learning: Harnessing the Hype. Performance Improvement, 41(2), 7-15.

Csikszentmihalyi, M. (1990). Flow: The psychology of optimal experience. New York: Harper Collins.

Davis, W. A. (1982). A Causal Theory of Enjoyment. Mind, New Series, 91(362), 240-256.

Di Blas, N., \& Poggi, C. (2006). 3D for Cultural Heritage and Education: Evaluating the Impact. Museums and the Web 2006 Conference, March 22 - 25, Albuquerque, NM., Retrieved October 24, 2006 from: http://www.archimuse.com/mw2006/papers/diblas/diblas.html

Dorussen, H., Lenz, H., \& Blavoukos, S. (2005). Assessing the Reliability and Validity of Expert Interviews. European Union Politics, 6(3), 315-337.

Eisenhardt, M. K. (1989). Building Theories from Case Study Research. Academy of Management Review, 14(4), 522-550.

Fisher, A. (2002, April). A Better Way to Learn: Understanding e-Learning. FT.com website. Retrieved August 1, 2006 from: http://specials.ft.com/elearning/FT3W67AL2ZC.html

Flick, U. (2003). An Introduction to Qualitative Research, 2nd Ed. London: Sage.

Ford, M. E. (1992). Motivating Humans: Goals, emotions, and personal agency beliefs. Newbury Park, CA.: Sage.

Forrester, D., \& Jantzie, N. (2004). Learning Theory. University of Calgary website. Retrieved September 13, 2004 from: http://www.acs.ucalgary.ca/ gnjantzi/learning theories.htm

Gee, J. P. (2003). What Video Games Have to Teach Us about Learning and Literacy. ACM Computers in Entertainment, 1(1), 1-4. 
Gilliver, R. S., Randall, B., \& Pok, Y. M. (1998). Learning in Cyberspace: Shaping the future. Journal of Computer Assisted Learning, 14(3), 212-222.

Goldman K. H., \& Wadman, M. (2002). There's Something Happening Here, What It Is Ain't Exactly Clear. Museums and the Web 2002 Conference April 17 - 20, 2002, Boston, MA. Retrieved October 24, 2006 from: http://www.archimuse.com/mw2002/papers/haleyGoldman/haleygoldman.html

Hoffman, D. L., \& Novak, T. P. (1996). Marketing in Hypermedia Computer-Mediated Environments: Conceptual foundations. Journal of Marketing, 60(3), 50-68.

Horniblow, J. (2004). Developing the Strategy for Change and Redevelopment of your Web Site. Museums and the Web 2004 Conference, March 31 - April 3, Washington, DC. Retrieved August 4, 2006 from: http://www.archimuse.com/mw2004/papers/horniblow/horniblow.html

Horton, W. (2000). Designing Web-Based Training: How to teach anyone anything anywhere anytime. New York: John Wiley \& Sons.

IBM Corporation and Economist Intelligence Unit (2003). The 2003 e-Learning Readiness Rankings. A White Paper from the Economist Intelligence Unit and Written with IBM.

ICOM (2006). ICOM Definition of a Museum. Retrieved October 27, 2006 from: http://icom.museum/definition.html

Iverson, K. M. (2004). e-Learning Games: Interactive learning strategies for digital delivery. Upper Saddle River, NJ.: Pearson Education.

Jakob, N. (2000). Designing Web Usability: The practice of simplicity. Indianapolis, IN.: New Riders.

Joint, N. (2003). Information Literacy Evaluation: Moving towards virtual learning environments. The Electronic Library, 21(4), 322-334.

Kaye, A., \& Poletto, P. (2004). Virtual vs. Physical: Creating on-line educational experiences through design. Museums and the Web 2004 Conference, March 31 - April 3, Washington, D.C. Retrieved August 4, 2006 from: http://www.archimuse.com/mw2004/papers/kaye/kaye.html

Knowles, M. S. (1975). Self-Directed Learning: A guide for learners and teachers. Englewood Cliffs, NJ.: Prentice Hall/ Cambridge.

Lawton, B., \& Gregor, D. S. (2002). Internet Marketing Communications: Interactivity and Integration. Seeking Success in e-Business: A multidisciplinary approach. IFIP8.4 Conference, June 9 - 12, Copenhagen.

Lieberman, J. N. (1977). Playfulness: Its relationship to imagination and creativity, 2nd Ed., New York: Academic Press. 
Maslow, A. H. (1987). Motivation and Personality, 3rd Ed., New York: Harper \& Row.

Marable, B., \& Incognita, T. (2004). Experience, Learning, and Research: Coordinating the multiple roles of on-line exhibitions. Museums and the Web 2004 Conference, March 31 - April 3, Washington, D.C. Retrieved August 4, 2006 from: http://www.archimuse.com/mw2004/papers/marable/marable.html

Mazoue, J. G. (1999). The Essentials of Effective Online Instruction. Campus-Wide Information Systems, 16(3), 104-110.

Minichiello, V., Aroni, R., Timewell, E., \& Alexander, L. (1990). Indepth Interview: Researching people. Cheshire, UK.: Longman.

Moody, J. W., Blanton E. J., \& Will, R. P. (1998/99). Capturing Expertise from Experts: The need to match knowledge elicitation techniques with expert system types. The Journal of Computer Information Systems, 39(2), 89-95.

Museum Domain Management Association (2006). Internationalized Domain Names (IDN) in .museum: Introduction, Retrieved August 1, 2006 from: http://about.museum/idn/

Neal, L., Magazine, L., \& Wormer, K. V. (2004). Making Learning Fun: Plimoth plantation's online learning centre. Museums and the Web 2004 Conference, March 31 - April 3, Washington, D.C. Retrieved August 4, 2006 from: http://www.archimuse.com/mw2004/papers/neal/neal.html

Pace, S. (2004). A Grounded Theory of the Flow Experiences of Web Users. International Journal of Human-Computer Studies, 60(3), 327-363.

Patton, M. Q. (2002). Qualitative Evaluation and Research Methods, 3rd. Ed., Thousand Oaks, CA.: Sage.

Perry, D. L. (1967). The Concept of Pleasure. The Hague: Mouton \& Co.

Powell, A. T. (2002). Web Design: The complete reference, 2nd. Ed. New York: McGrawHill/Osborne.

Preece, J., Rogers, Y., Sharp, H., Benyon, D., Holland, S., \& Carey, T. (1994). Human Computer Interaction. Wokingham, UK.: Addison-Wesley.

Prensky, M. (2000). Digital Game-Based Learning. New York: McGraw-Hill.

Rossman, G. B., \& Rallis S. F. (2003). Learning in the Field: An introduction to qualitative research, 2nd. Ed., Thousand Oaks, CA.: Sage.

Schaller, D. T., Allison-Bunnell, S., \& Borun, M. (2005). Learning Styles and Online Interactives. Museums and the Web 2005 Conference. Vancouver, Canada, April 13 - 17. Retrieved October 24, 2006 from: http://www.archimuse.com/mw2005/papers/schaller/schaller.html 
Seligman, M. E. P., \& Csikszentmihalyi, M. (2000). Positive Psychology: An introduction. American Psychologist, 55(1), 5-14.

Silberman, H. F. (1972). Applications of Computers in Education. In R. C. Atkinson \& H. A. Wilson (Eds.) Computer-Assisted Instruction: A book of reading. (pp. 49-61). Stanford, CA.: Stanford University Press.

Sommerville, I. (2001). Software Engineering, 6th. Ed., Harlow, UK.: Addison-Wesley.

Steinkuehler, C. A. (2004). Learning in Massively Multiplayer Online Games. ICLS 2004: International Conference on Learning Sciences, June 22 - 26, Los Angeles. Proceedings of the 6th International Conference on Learning Sciences, $521-528$.

Stopsky, F. (2000). The Internet and the quest for knowledge. College Teaching, 48, 37-38.

Tarasewich, P., Harold, D. Z., \& Hampton, G. E. (2001). Aesthetics and Web Site Design. Quarterly Journal of Electronic Commerce, 2(1), 67-81.

Taylor, S. J., \& Bogdan, R. (1984). Introduction to Qualitative Research Methods: The search for meanings, 2nd. Ed., New York: John Wiley \& Sons.

Telfer, E. (1980). Happiness. London: Macmillan.

Thomas, R. M., \& Kobayashi, V. N. (1987). Educational Technology: Its creation, development, and cross-cultural transfer. Oxford: Pergamon.

Thompson, R. L., Higgins, C. A., \& Howell, J. M. (1991). Personal Computing: Toward a conceptual model of utilization. MIS Quarterly, 15(1), 125-143.

Tucker, E. (1997). The Impact of CAL in a University Engineering School. Education and Training, 39(6/7), 271-274.

Veenhoven, R. (1984). Conditions of Happiness. Dordrechy, The Netherlands: D. Reidel.

Warner, R. (1980). Enjoyment. The Philosophical Review, 89(4), 507-526.

Weber, R. P. (1990). Basic Content Analysis, 2nd. Ed., Newbury Park, CA.: Sage.

Webster, J., \& Martocchio J. J. (1992). Microcomputer Playfulness: Development of a Measure with Workplace Implications. MIS Quarterly, 16(2), 201-226.

White, A. R. (1964). The Notion of Interest. The Philosophical Quarterly, 14(57), 319-327.

Wofford, J. L., Smith, E. D., \& Miller, D. P. (2005). The Multimedia Computer for Office-based Patient Education: A systematic review. Patient Education and Counseling, 59(2), 148157. 
Yang, C. T., \& Ho, H.C. (2005). A shareable e-Learning Platform Using Data Grid Technology. Proceedings of the 2005 IEEE International Conference on e-Technology, e-Commerce and e-Service (pp. 592-595), March 28 - 31, Hong Kong, PRC.
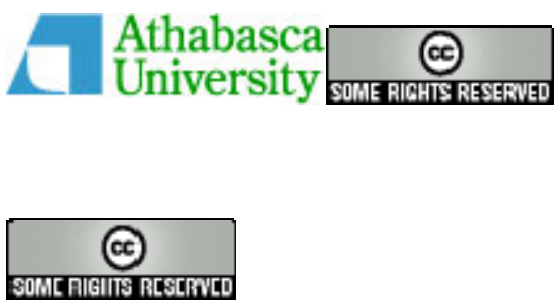